WellBeing International

WBI Studies Repository

$11-1-2003$

\title{
The Problem of Unwanted Pets: A Case Study in How Institutions "Think" about Clients' Needs
}

Leslie Irvine

University of Colorado Boulder

Follow this and additional works at: https://www.wellbeingintlstudiesrepository.org/acwp_ca

Part of the Animal Studies Commons, Civic and Community Engagement Commons, and the Nonprofit Administration and Management Commons

\section{Recommended Citation}

Irvine, L. (2003). The Problem of Unwanted Pets: A Case Study in How Institutions" Think" about Clients' Needs. Social Problems, 50(4), 550-566.

This material is brought to you for free and open access by WellBeing International. It has been accepted for inclusion by an authorized administrator of the WBI Studies Repository. For more information, please contact wbisr-info@wellbeingintl.org.

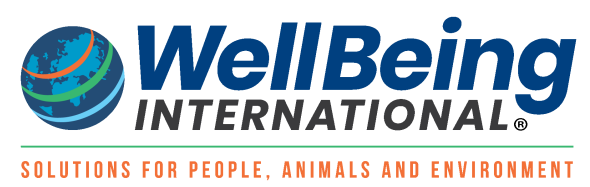




\title{
The Problem of Unwanted Pets: A Case Study in How Institutions "Think" about Clients' Needs
}

\author{
LESLIE IRVINE, University of Colorado at Boulder
}

\begin{abstract}
The research on organizational framing and the metaphor of institutional "thinking" highlight the ways that social problems organizations shape the ameliorative services they deliver. Social problems work then perpetuates representations of problems that may not match the conditions clients face. This study extends social problems literature to argue that organizations sometimes "think" differently about the problems they intend to solve than do persons involved with these problems in everyday life. Using ethnographic research and interviews, this article contrasts the way in which animal sheltering, as an institution, frames the problem of unwanted animals with how the public interprets that problem. Institutional "thinking" portrays pets as commitments for life, and shelters thus strive to offer resources that allow people to keep their animals in their homes. However, interviews reveal that most people simply want troublesome animals out of their homes. This mismatch of intentions sheds new light on the complexities of claims-making and social problems work. In particular, the "paradox of popularization" means that efforts to gain public support for definitions of social problems often ignore or exacerbate aspects of problems that do not fit institutional frames.
\end{abstract}

The organizations charged with ameliorating social problems tend to "think," as Mary Douglas (1986) put it, in certain ways (see Holstein and Miller 1993; Miller and Holstein 1989). In this article, I use the notion of institutional "thinking" as a metaphor for the interpretive practices that become apparent in organizational discourse. Institutions "think" for those within their purview by providing models through which experience is processed. As a guiding metaphor, institutional "thinking" reveals how an organization's discourse and activities help to reproduce characteristic definitions of and solutions to social problems. From within an organization, a solution to a social problem "is only seen to be the right one if it sustains the institutional thinking that is already in the minds of individuals as they try to decide" (Douglas 1986:4, my emphasis). For example, in Jaber Gubrium's (1992) study comparing two treatment facilities for family problems, he finds that the "overriding contrast between the two institutions lies in their images of domestic disorder" (p. 18). One facility defines domestic disorder as a problem of authority; the other uses emotional terms. Nevertheless, "whatever background differences or similarities patients and families bring to the organizations," Gubrium writes, "and regardless of the administrative differences or similarities encountered in the settings, these images sort the particulars" (1992:19; see also Miller 1987). Because the template of institutional thinking frames social problems selectively, the solutions offered do not necessarily address the problems as experienced by persons outside the institutional purview. Institutional thinking ignores salient aspects of the conditions persons may associate with the problem in everyday life, which later emerge through the cracks, as it were, of the "organizationally embedded" solutions (Gubrium 1992).

The author wishes to thank Patti and Peter Adler, James Holstein, and the incredibly thorough reviewers of Social Problems for helpful comments on previous drafts. Direct correspondence to: Leslie Irvine, University of Colorado, Department of Sociology, 219 Ketchum 327 UCB, Boulder, CO 80309-0327. E-mail: irvinel@colorado.edu.

SOCIAL PROBLEMS, Vol. 50, No. 4, pages 550-566. ISSN: 0037-7791; online ISSN: 1533-8533

(C) 2003 by Society for the Study of Social Problems, Inc. All rights reserved.

Send requests for permission to reprint to: Rights and Permissions, University of California Press, Journals Division, 2000 Center St., Ste. 303, Berkeley, CA 94704-1223. 
The concept of "social problems work" (Holstein and Miller 1993; Miller and Holstein 1989) refers to a cluster of activities that are associated with institutional thinking. Social problems work encompasses the claims-making activities that were the original focus of analyses of the social construction of social problems (e.g., Spector and Kitsuse 1973, 1987). It also includes the interpretive and rhetorical work involved in the production and reproduction of "collective representations" (see Holstein and Miller 1993; Miller and Holstein 1989), or the "typifications" of social problems. For instance, "crack babies," "abused wives," "victims of crime," "welfare mother," and "alcoholic" are all "collective representations" that offer us an understanding of conditions and categories of people beyond those we personally experience (see Loseke 1999). Because social problems work involves creating new typifications and elaborating distinctions that produce new understandings of existing social problems, it has a role in the production of culture (Miller and Holstein 1989, 1997). Analyses of social problems work extend the claims-making approach developed by Malcolm Spector and John Kitsuse (1973) to show how these interpretive activities "are related to other social, cultural, and political processes, particularly, how claims-making may perpetuate or change prevailing patterns of action and relationship in society" (Miller and Holstein 1989:4).

Social problems work not only creates problems and poses solutions, but also "produces" clients in particular ways. For example, Donileen Loseke examines how workers in a shelter for abused wives define some women as "battered" and thus as "appropriate clients" for their services $(1989,2001)$. J. William Spencer (1994) turns attention away from workers and examines the role of clients in institutional thinking. He develops the term "client work" to highlight ways that homeless clients construct their biographies to cast themselves as worthy of the services of the Homeless Assistance agency. These studies and others show how service organizations perpetuate their own definitions of the problem and those affected by it (see also Holstein 1992; Miller 1983, 1992).

This study examines social problems work within the institutional setting of an animal shelter. Specifically, it compares the way one shelter "thinks" about why people give up unwanted animals with how clients see their reasons for doing so. The term used for the process of giving up an animal is "surrender." This, in itself, represents some of the social problems work that takes place within sheltering. Although clients are abandoning their animals, the gentler term of "surrender" helps produce an image of the "good" client, in contrast to those who leave their animals to fend for themselves. Through this rhetorical practice and others, shelters frame the problem of unwanted pets in ways that encourage public support for their efforts. That frame, however, ignores aspects of the problem that do not fit within its borders.

I begin by providing a history of the emergence and evolution of the problem of unwanted animals. In particular, I focus on the connections between social problems work and culture. Stray animals first became a problem during urbanization, and their welfare became a problem once certain people became concerned with the moral standing of animals. In this way, the construction of the unwanted pet problem illustrates that, as Stanley Cohen (1985) puts it, "the very idea that a social problem is solvable needs an appropriate belief system" (pp. 197-8; see also Miller 1997). Following this history, the article contrasts contemporary institutional thinking about the problem of unwanted animals with the lay public's perception of the same problem. Shelters tend to think about pets as commitments for life, and thus offer resources aimed at enabling people to solve or manage animal problems and keep their pets. However, interviews show that most people are simply unaware of or unwilling to use the resources that shelters offer. Instead, they want the animal out of their homes. Because animals continue to arrive at shelters-despite low-cost sterilization, abundant training opportunities, and easy access to reliable information about animal health and behavior-the question is whether the institutional thinking is the right way to think about the problem of unwanted pets. 


\section{Methods and Setting}

This article draws on data collected and analyzed through emergent inductive techniques (Becker and Geer 1960). The primary source is over 300 hours of ethnographic research at a humane society which I will refer to as "The Shelter." This private, non-profit organization offers adoptions, veterinary services, humane education, dog training, and cat behavioral consultations, and serves as headquarters for the city's animal control services and welfare investigations. The Shelter takes in animals regardless of age, breed, or condition. It is among a small but growing number of shelters in the country that do not euthanize healthy animals. However, it is not a "no-kill" facility; animals are put to death if they are considered unadoptable due to serious, untreatable health or behavior problems. A well-run Foster Care program provides temporary housing for very young puppies and kittens and for animals who would be killed in other facilities because they are not immediately adoptable. The Shelter takes in approximately 5,000 unwanted animals per year, which is a low number within the animal welfare industry. About 85 percent end up in new homes.

In 1998, I began working as one of The Shelter's volunteers. A year later, intrigued by the dynamics of the place, I gained permission to study the surrender process. I moved into what Peter and Patricia Adler (1987) call a "complete membership role." I continued working as a volunteer, but also began observing surrenders, recording notes and examining them regularly in search of emergent themes and patterns. Eventually, I began interviewing clients who surrendered animals. The Shelter generously helped me recruit interviewees by attaching an information and consent form to the surrender paperwork. This resulted in 40 indepth interviews on surrender decisions. Meanwhile, I also observed Shelter workers and talked with them about their experience and understanding of the surrender process.

In short, this article draws on intensive participant observation, interviews, and field conversations. The strength of the research is that it offers a more nuanced picture of the surrender process than do existing surveys, which reduce the reasons for surrender to a single word (e.g., Kass et al. 2001; New et al. 1999; Salman et al. 1998). Nevertheless, this research also has some limitations. First, it examines only a single setting in a racially and economically homogenous part of the country, the residents of which are predominantly white, educated professionals. Second, the setting in the Mountain region of the U.S. has the highest rate of pet ownership nationwide, with 64.8 percent of all households reporting companion animals (AVMA 1997). Third, The Shelter is "progressive" in several ways. It has an opendoor admission policy, which means that it accepts animals regardless of age, breed, or condition. It strives for adoption rather than euthanasia. In order to accomplish this, it uses "open" adoption policies, which subject potential guardians to far less scrutiny than do "traditional" policies that involve rather extensive probing into guardians' abilities to care for animals (see Balcom and Arluke 2001). Although the less intimidating open policies "encourage more adoptions and community support" (Balcom and Arluke 2001:136), we shall soon see the disadvantages to minimizing scrutiny. Finally, The Shelter is unique in its emphasis on equipping people to be responsible guardians (an approach which we shall also soon examine). However, the factors that make the region and the organization unrepresentative-the combination of high levels of pet ownership, high education, and a progressive organizational culture-also make it useful as a case study. Specifically, The Shelter offers the opportunity to study surrender decisions among people who appear to value companion animals and who have the education and resources to consider alternatives to surrender.

\section{Constructing the Problem of Unwanted Pets in the United States}

At the time of the Civil War, there was no such thing as a "homeless pet" and, consequently, no "animal shelters." To be sure, unowned dogs and cats wandered the streets and 
countryside. However, homeless animals did not constitute a social problem until claims-makers began the work of portraying them as such. During the nineteenth century, fear of rabies prompted American city governments to authorize the capture of roaming animals, particularly dogs. ${ }^{1}$ In the absence of any solid etiology about the disease, rabies was assumed to generate spontaneously. The logical preventive measure was to eliminate stray animals. The claims-makers in the battle for animal control were public health officials, veterinarians, and scientists who, though they had no explanation for patterns of rabies outbreaks, nevertheless persuaded city officials to enact rabies control measures. Municipalities authorized local constables and the infamous "dog catchers" to hunt and catch stray dogs, often for a bounty (McHugh 1999; Palmer 1978). In addition, many American (and European) cities implemented dog licensing laws. Similar efforts to establish cat licensing laws failed, and the practice of licensing dogs accomplished little. The regulations usually applied to dogs over six months of age and effectively restricted ownership to those who could afford the fees (see Kete 1994; Ritvo 1987; Thomas 1983). To avoid paying the licensing fees, many people simply let their dogs loose once they passed the endearing puppy stage. Consequently, in most towns and cities, packs of dogs ran free and colonies of cats abounded, creating numerous potential and actual troubles. The lack of spaying or neutering greatly compounded the problem.

City pounds held animals for a prescribed period and killed the unclaimed by drowning or electrocution or sold them in quantity to vivisectors. ${ }^{2}$ Although the cities' efforts had reduced the numbers of roaming animals, the middle class in particular objected to the cruelty and mass killing through which this was accomplished. Early histories of the humane movement document the horrors of the city pounds (e.g., McRae 1910), and the image of the "dog catcher" itself speaks to the demonization of the agents of animal control.

In the 1860s, two Philadelphia women, Elizabeth Morris and Annie Waln, began going around the city picking up and sheltering strays (see Coleman 1924). Morris and Waln found homes for those they could and chloroformed the others, which was a more humane method than those used in the pounds. In 1874, the two started the first Animal Rescue League. In 1888, they incorporated their organization as the Morris Refuge Association for Homeless and Suffering Animals. It became a model for many humane shelters and still operates today. At about the same time, Caroline White, another Philadelphian, was similarly infuriated at the city's role in supplying animals for vivisection (see Coleman 1924; Unti 1998). White had spearheaded the formation of the Pennsylvania Society for the Prevention of Cruelty to Animals (PSPCA), but, as a woman, she could not hold an office (although her husband served on the Board). In its second year, the PSPCA proposed a "Women's Branch," and White became president, a position she held until her death in 1916. The many humane accomplishments of the Women's Branch include the first contract with a city government to shelter strays. Philadelphia contributed $\$ 2,500$ toward the costs. This constitutes "the first attempt on the part of any society in the United States to handle the problem of caring for surplus or unwanted small animals, and as far as it can be ascertained the first appropriation ever made by a municipality for humane work" (Coleman 1924:181; see also Brestrup 1997). In Loseke's (1999) terms, the Women's Branch had won an important victory in the "social problems game" by convincing the city to do this.

The establishment of the first shelters prompts three observations about social problems work. First, it highlights how social problems claims-making establishes the link between the contemporaneous moral climate and the timing of problems construction (see Cohen 1985; Loseke 1999; Miller 1997). Concurrent social problems work during the late nineteenth century,

1. Although no extant literature describes the American case, Kete (1994) and Ritvo (1987) examine Paris and England, respectively.

2. In the United States, unclaimed animals were routinely sold for use in research throughout most of the twentieth century. The Metcalf-Hatch Act, which was repealed in 1979, required the practice, called "pound seizure" (see Finsen and Finsen 1994). 
such as the founding of the American Society for the Prevention of Cruelty to Animals (ASPCA) and anti-vivisection organizations, fomented concern from an ethical or moral standpoint about humans' treatment of animals (see Franklin 1999; Ritvo 1987; Serpell 1986; Thomas 1983). Prior to this, there was no belief system (or none with enough popular support) defending the welfare of stray dogs and cats. Second, and related to this, the emergence of the first shelters reveals fragmentation within a moral climate (Loseke 1999). Fragmentation means that people will often "unite at the extremes" (Loseke 1999:180) of social problems, making them the points where claims-making will be most effective. In the context of animal welfare, not everyone would agree on the particulars of animals' moral standing, but most would disapprove of torture and suffering. The audience united at the extreme-agreeing that killing needed to be humane-so this was where the claims were most successful. Third, the creation of the first shelters reveals the construction of victims and villains, two necessary components of defining a condition as a social problem (see Loseke 1999). The animals were those most harmed by the inhumane killing, but within the moral climate of the humane movement, the horrors of the city pounds also diminished humanity itself. The city governments and "dog catchers" responsible for the killing were the villains, but the people who let their animals wander were implicated as well.

The phenomenon of "uniting at the extremes" and the construction of villains and victims combined to give "audience members neat and tidy images" of the animal problem (Loseke 1999:94). The resulting simplistic image framed the problem and assigned blame, but simultaneously obscured the complexity of the underlying conditions. This situation would endure into the present.

\section{Reconstructing the Popular Frame: Piggybacking}

As Loseke explains, one effective strategy for expanding claims about social problems involves constructing a new problem as a different instance of an existing one (1999:82). An example of this strategy, known as piggybacking, is apparent in how claims about civil rights for African Americans made it easier for subsequent groups to make claims about their right to equality. Piggybacking nicely describes the ways that animal welfare claims-makers expanded the frame around the problem of stray animals to include a new version of the problem of unwanted pets.

Although stray animals continued to populate shelters throughout the twentieth century, facilities also began taking in litters of puppies and kittens for whom their human guardians were unable to find homes. The innocence of puppies and kittens made them the ideal "victims," epitomizing the "deserving" shelter animal. In terms of piggybacking, taking in puppies and kittens was simply an effort to reduce the troublesome strays of the future. As the population of shelters consequently changed, the social problems work within sheltering shifted its practices, from solving the problem of stray animals to reducing reproduction. In the 1970s, a nationwide campaign to educate the public about the need for sterilization gradually reduced the flow of litters into shelters. Joint claims-making efforts on the part of the American Veterinary Medical Association, The American Humane Association, The Humane Society of the United States, The American Kennel Club, and The Pet Food Institute framed the problem as one that would respond to education about sterilization and free or discounted spay and neuter clinics. In addition, legislation began to require the sterilization of adoptable animals in shelters so that no dogs or cats who left a shelter could contribute to the problem that had led them there in the first place.

Thirty years later, shelters continue to receive an unending supply of animals, but the population dynamics have changed again. To be sure, sterilization remains a core aspect of the social problems work within sheltering; witness the "Spay and Neuter" stamps released by the U.S. Postal Service in 2002. Whereas positive strides in sterilization have reduced the numbers of litters, the new majority of shelter animals are adults who failed to become the kind of 
pets for which their guardians had hoped. This has resulted in another institutional re-framing of the "problem" of unwanted animals. In the 1990s, sheltering organizations began to consider what else (besides sterilization) could "stop the flow of animals into the building" (Lawson 2000:10). The local culture of animal sheltering framed its task as increasing the likelihood that people would keep their dogs and cats for life (Irvine 2002; McHugh 1999). This expanded the scope of social problems work to include educating the public about animal health, behavior, and training. As part of this effort, shelters began remaking themselves as resource centers and not just last resorts. In order to draw people in to seek these resources, shelters sought to become more pleasant places for human and non-human animals.

A large part of this make-over addressed the image of shelters as death chambers. Until roughly the 1990s, the institutional discourse of sheltering portrayed putting unwanted animals "to sleep" as an act of mercy (see Brestrup 1997). The moral climate changed when claims-makers within sheltering began to voice opposition to the mass killing. ${ }^{3}$ This prompted new efforts to re-home a greater number of animals. Shelters have had to stop "waiting patiently for customers to come to them and instead develop more aggressive adoption strategies" (Brestrup 1997:44). ${ }^{4}$ Increasing adoptions meant stepping up public relations efforts, including making adoptable animals more visible through newspaper photos, websites, and bringing them to the people (at community events), rather than waiting for people to come to them.

The animals remained the victims in the reframed "problem" of unwanted pets, but the new claims required a new villain. If shelters were to market themselves as resource centers, then the new villain must be the person who does not use those resources. More specifically, the new villain is an irresponsible, unloving person who does not bring the unwanted animal to a shelter. Shelter workers warn the public of the fates that await animals "on the streets," or, worse still, when they are offered "Free to a Good Home." Such ads often bring people in search of dogs, in particular, to sell to dealers who then sell them to medical research labs. ${ }^{5}$ The images of the uncertainty animals will face when they are not surrendered to a shelter parallels successful cases of claims construction that depict the "horrifying consequences" other types of victims will face (Loseke 1999:86). Similar horror stories include the cases of "missing children" (Best 1990), "abused children" (Johnson 1995), and "abused wives" (Loseke 1989, 1992).

The production of the villain implies the concurrent production of the "good" shelter client. Evidence of this production appears in the way shelters train workers to accept the reasons that guardians offer for surrender without criticism. If surrenderers feel guilty, the logic goes, they will avoid shelters, and animals will face "horrifying consequences." The local culture of shelters thus "creates" guardians who surrender dogs or cats as those who are doing the right thing for the animals. To "produce" clients as the "good" ones, The Shelter trains workers not to judge, criticize, or even ask probing questions about surrenders, but to take only the necessary information. The intake paperwork requires only a brief, single reason for the surrender, and the computer program that generates it does not allow for lengthy accounts. Indeed, the software forces staff members to select the best reason from options on a pull-down menu. The application of formal rationality in this way promotes the predictability that bureaucracy requires. However, the social problems work involved in sustaining the image of "good" clients may also perpetuate the problem that shelters set out to solve. To examine how this occurs, I turn to the empirical data.

3. The first published evidence that I located was a 1989 essay by Ed Duvin in animalines, a publication for animal care professionals.

4. One nationwide effort of this sort is the "Pets for Life" campaign of The Humane Society of the United States.

5. Unlicensed brokers known as "bunchers" seeking to collect free dogs in this way will even bring children with them to create the impression that the animal will go to a family. "Bunchers" obtain animals from such ads, along with strays and unclaimed dogs from veterinary hospitals (they offer to find homes for them). They then sell them to Class B dealers for around $\$ 25$ each. Class B dealers offer a broader variety of dogs less expensively than Class A dealers, who breed dogs intended specifically for research (see Reitman 2000). 


\section{Guardians' Accounts of Surrender Decisions}

Reducing the surrender decision to a single reason allows for tracking of the frequency with which guardians offer particular reasons (e.g., Arkow and Dow 1984; Kass et al. 2001; Miller et al. 1996; New et al. 1999; Salman et al. 1998, 2000; Scarlett et al. 1999). Many of the organizations and groups seeking solutions to the problem of unwanted animals have made use of such data. However, interviews with guardians reveal that basing solutions on surrender data is problematic because the reasons for surrender follow institutionally embedded formulas. Relying on statistical data reproduces institutional thinking that ignores or even exacerbates the conditions that lead guardians to surrender.

Judging by frequency of occurrence, I found that the top three reasons offered by guardians for the surrender of dogs and cats were moving, allergies, and behavior problems. The latter category included such things as incompatibility with other animals in the household (commonly mentioned among dogs and cats) and elimination problems (common among cats). Other studies corroborate the frequency with which guardians nationwide offer these reasons (Arkow and Dow 1984; Kass et al. 2001; Miller et al. 1996; New et al. 1999; Salman et al. 1998, 2000; Scarlett et al. 1999). Thus, according to frequency of occurrence, a major cause of homeless animals is that guardians were moving into places that either did not allow animals or limited the number of animals allowed. It would then seem that making rental housing pet-friendly could go a long way towards solving the problem of homeless animals. Indeed, this is precisely what The Shelter has tried to do. Like many shelters across the country, The Shelter makes available, both on paper and on-line, a list of "Animal Friendly Housing" in the area. Yet, when I asked guardians what steps they had taken to locate housing that would allow their animals, the answer usually boiled down to "none." To be sure, it appeared among other reasons. For example:

- Well, no, but that's because I'm moving in with my boyfriend and his complex doesn't allow animals.

- No. I looked at a couple of places and they didn't allow pets so I just took the one I could afford and didn't look anymore.

- We didn't really try to find a place that would let us have pets because we've been thinking about traveling.

The reasons people offer for relinquishment reveal only a partial picture of the decision process. Through interviews, I found that multiple circumstances contribute to the decision to surrender an animal. This finding is consistent with the results of other qualitative studies of surrender (see DiGiacomo, Arluke, and Patronek 1998). This finding also resonates with Loseke's (2001) discussion of the complexity of the lived experience of battered women. In her study of a battered women's shelter, the problem that is institutionally categorized as a "failed relationship" is experienced by many women as "many simultaneous, interrelated, and vaguely defined troubles" (p. 108). Similarly, a single reason such as "Moving" might have been the one recorded for surrendering an animal, but this categorization was the product of the interpretive demands of The Shelter's intake paperwork (see Gubrium, Buckholdt, and Lynott 1989). In a case of what Gubrium and associates (1989) call the "tyranny of forms," the paperwork makes demands on the staff members who complete them, requiring brief, standardized accounts of complex situations. However, my interviews unearthed numerous factors that contributed to the decisions, attesting to what Loseke calls the "messiness" of lived experience. For example, in this interview excerpt, a guardian (G) who surrendered her cat because she was moving reveals other reasons for her decision:

G: I could have taken her with me, but I would have had to pay the pet deposit.

LI: How much was it?

G: One hundred dollars. 
LI: A month or a year?

G: No, just a one-time thing, along with the security deposit. An extra \$100.

LI: And you'd get it back when you moved again?

G: Well, yeah, if there was no damage. But anyway, she was really bothering me, the way she'd wake me up early all the time. I loved her and all, but she was bugging me. And she sheds all the time, too. I mean, there's fur all over everything!

The woman's unwillingness to take the cat with her presents a more complex picture than does a simple, "I'm moving." The cat's early morning hours had been "bugging" her and she objected to the shedding-both normal, inevitable aspects of life with cats. The move presented an opportunity to weigh her relationship with the cat, and, in this case, it was not worth $\$ 100$.

People who surrendered animals because someone in the household had allergies revealed similar bundles of reasons that defy the narrative conventions of the surrender paperwork. I interviewed a woman who surrendered a cat to whom she had become allergic and heard a medically unlikely "quasi-theoretical" explanation (Hewitt and Hall 1973). Quasi-theories impose order on otherwise inexplicable situations. In this case, the women explained that she had recently moved several times, but at the time of the interview, she "had a good situation" sharing an apartment with a female roommate who also had a cat. The woman denied any previous symptoms of allergies. She explained that her allergies had occurred because the two cats did not get along, and because her cat was the aggressor. The stress of that situation had, she claimed, made her allergic. I asked if she had seen a doctor about her symptoms, and she had not. Because there was still a cat in the household, I asked how the allergies were since she had surrendered her cat. She said she no longer had symptoms because the stress that had brought them on had disappeared. Although allergies are idiosyncratic immune responses, it is highly improbable that a fleeting sensitivity such as this could occur. Because allergens remain in an environment long after an animal leaves it, surrendering a cat will seldom bring immediate relief. Moreover, although many people claim that they are only allergic to certain cats, the research suggests that even "different breeds of cats seem to be strongly related allergenically" (Joneja and Bielory 1990:158). In short, a hypersensitivity to one cat will usually produce an allergic reaction to other cats, as well.

Like the woman in the above example, other guardians who surrendered an animal because of moving or allergies also admitted to having additional animals still at home. This concurs with the national studies, which report that 17 percent of guardians who surrendered one or more animals because of allergies had one or more remaining dog, cat, or both at home. More importantly, these guardians gradually revealed that the surrendered animal had done something to prompt the surrender, perhaps had urinated on the carpet or fought with another animal in the house. Similarly, in nationwide studies, 33 percent of those who surrendered dogs for reasons such as moving or allergies also reported a "nonaggressive behavioral problem in the dog surrendered" (Scarlett et al. 1999:45). In addition, most guardians had procrastinated about the surrender for some time, allowing bad situations to worsen until something eventually tipped the scales.

This procrastination until the appearance of a "last straw" has parallels in other behaviors, such as when people go to the doctor (see Pescosolido 1992; Zola 1973). The research suggests that people tend not to seek medical help when they are sickest, or even when a problem first appears. Instead, they delay until something else prompts them to make an appointment. Confronted with a tangled history of symptoms, the physician's job becomes more difficult. So it goes with problematic animals. However, even though people delay seeking medical care, most do eventually turn to the expertise of a physician for problems they cannot solve themselves. This is where the comparison ends. The pet guardian has the option of "solving" the problem by surrendering the animal. Many guardians do not turn to experts when it comes to the health and behavior of their animals. In the next section, I examine the factors that contribute to this failure to seek expert opinions, making surrender seem like the only option. 


\section{Blaming the Victim}

Although The Shelter offers numerous alternatives to surrender, adopting one or more of them would require understanding and defining the problem, isolating one problem from others, and accepting an uncertain outcome of, say, training or treatment. For example, a guardian who locates pet-friendly housing might find that her cat's urination problems continue in the new place, or the animals who remain at home after the surrender of the "troublemaker" might have been fighting for some other reason all along. Many guardians simply prefer surrender, which contrasts dramatically with The Shelter's thinking about a lifetime relationship with an animal.

Most people did not consider alternatives to surrender because of a lack of basic knowledge about animals, which results in an inflated estimation of one's expertise. The lack of knowledge also produces unrealistic expectations about what animals are like and what they need. In interviews, I found that most dog guardians mistakenly thought that a female dog could not be spayed while in heat and that neutering a male dog before adulthood would stunt his growth. In research sponsored by the National Council on Pet Population Study and Policy, a majority of people (61 percent) surrendering animals thought, incorrectly, that dogs and cats should mate at least once before being sterilized (or they did not know whether this was true). ${ }^{6}$ Only about 20 percent of those surrendering cats were aware that females are seasonally polyestrous, meaning that they can go into heat and bear several litters over a season. Among those surrendering dogs, 43 percent did not know how often female dogs experience estrus (the answer is twice a year). About half of those relinquishing dogs or cats also thought (incorrectly) that animals misbehave to spite their guardians. Similarly, Clinton Sanders (1994, 1999) found considerable ignorance about the care of animals among the clients in the veterinary practice that he studied. Much of the vets' time went to educating clients and providing instructive literature.

Inadequate knowledge led to a failure to seek information and treatment for animals' health or behavior problems, much of which was available through The Shelter. Although many guardians had taken their animals to a vet upon first acquiring him or her, few had consulted vets further once behavioral problems appeared, even when the problems seemed health related. Moreover, many of the behavior problems occurred among animals who were sexually intact at the time of surrender, but few guardians associated the two factors. Other studies consistently reveal an association between the failure to sterilize an animal and increased risk of relinquishment (Patronek et al. 1996a, 1996b; Salman et al. 1998, 2000; Scarlett et al. 1999; Shore and Girrens 2001).

Few guardians had consulted behaviorists or trainers, both of whom are readily available in the area. In addition, most of the surrendered dogs had received no training, which is consistent with the findings of other studies. The Shelter offers a free "Canine Behavior" seminar and six months of feline behavioral counseling with each adoption. Yet these resources go woefully underused. Because no one can be required to use them, guardians who choose not to do so miss learning even the basic knowledge that might allow them to keep a newly adopted animal in their home. For instance, a woman returned a dog whom she had adopted just two weeks earlier, saying she could not housebreak him. When asked if she had tried crate training the dog, which is The Shelter's endorsed method for ensuring successful housebreaking, she said she had never heard of it. In saying so, she revealed that she had neither attended the seminar nor read the material included in her adoption packet, as both convey

6. Quick calculations reveal the implications of this for the animal population. Let us turn 61 percent into 61 people, and give them each one dog or one cat. If we allowed each dog or cat to have one litter before sterilizing the animal, the first year those 61 animals would bear 244 puppies and kittens, if they only had litters of four, which is conservative. The next year, the offspring, who then had their pre-sterilization litters of four, would produce 976 additional puppies and kittens. By the third year, with those 976 bearing four young each, the number of births would be 3,904. 
how-to instructions on the topic and information about The Shelter's crate rental program. Instead, she explained that she had repeatedly rubbed the dog's nose in his urine and fecesan ineffective method that will apparently take generations to disappear.

Because many people considered their existing stock of knowledge about animals accurate and sufficient, they lay the blame for behavior problems on the animal. When a dog or cat does not behave correctly, guardians assume there must be something wrong with the animal and they become emotionally disconnected from the animal as time goes on. Guardians in this position often used the language that Sanders (1999) calls "unlinking." This

... is a public confession that the animal-human relationship itself is in serious trouble. Frustrated and confused, the guilt-ridden owner publicly acknowledges that the animal other is "out of control" ("I just don't know what to do. I can't get him to stop barking. I've tried and tried but nothing seems to work") . . . The fault for the disruptive action is presented as being the animal's and, in turn, the owner is absolved of responsibility. Understandably, the owner who comes to employ this type of excusing tactic is well on the way to ending his or her relationship with the animal. (P. 36)

Unlinking is lay social problems work, in that it rhetorically casts the "problem" as the animal's rather than the person's. Moreover, unlinking language indicates that the animal's behavior is so threatening to the guardian's self-image that he or she has disengaged from any emotional and relational connection with the animal. For example, a man I interviewed had surrendered a large dog who pulled constantly on his leash. The family had hoped the dog would be a companion for the young son, who, as it turned out, was not strong enough to walk him. However, no one took any steps to teach the dog to walk without pulling. The fatalistic tone of unlinking is evident in this interview excerpt:

G: It just wasn't any fun to walk him. He could pull you down the street. We just didn't know what else to do.

LI: Did you have him in training classes?

G: No. We never got around to that. We meant to, and then it just seemed impossible. We just gave up walking him.

LI: Did you try a Gentle Leader?

G: Yeah. We put it on him once and he didn't like it so we stopped using it.

LI: So how did he go for walks?

G: Well, that's just it. He didn't. We just left him in the yard. We just went out there to feed him. He was in the yard all the time. He's just not the right dog for us. We don't know what else to do.

This guardian had tried nothing and consulted no one, yet claimed that he did not know what else to do.

Most people simply did not know about the resources available to them as alternatives to surrender. In the case of allergies, interventions such as shots and prescription medications can help tremendously. Yet, no one I interviewed had considered these; to the contrary, most expressed horror at the idea of shots or being "on medications." However, there are also products (Allerpet- $\mathrm{C}^{\oplus}$ for cats, and Allerpet- $\mathrm{D}^{\oplus}$ for dogs) to wipe on an animal's coat that neutralize the allergenic proteins. Most pet supply stores stock them (including The Shelter's) and I have also seen them in grocery stores, yet no one who surrendered an animal because of allergies had heard of them. Measures such as keeping the animal out of the bedroom, combined with thorough vacuuming of carpets and brushing of the animal (by a non-allergic person) can help. Granted, this requires commitment. Nevertheless, most people did not know of and hence had not tried any of these ameliorative measures.

The failure to seek information or assistance was particularly striking in the context of behavioral problems. Few people who surrendered dogs for aggression to other dogs had consulted with a behaviorist. The Shelter offers training classes and the trainers will do private consultations for specific problems, but most people I spoke with neither made use of these resources nor consulted their veterinarian during routine visits. This is particularly striking in light of evidence indicating that frequency of visits to a veterinarian is associated with decreased 
risk of relinquishment among dogs (Patronek et al. 1996b). Instead of seeking advice, however, many people simply surrendered their dogs, using unlinking language such as, "We just don't know what to do."

Many of the alleged behavior "problems" in dogs and cats stemmed from guardians' ignorance about breed characteristics or developmentally normal behaviors. For instance, several guardians defined their dogs' behavior problem as "hyperactivity." Because many of the surrendered dogs were under two years old, these guardians held unrealistic expectations of the behavior and exercise requirements of young dogs. This was also the case when people acquired herding breeds or dogs with high prey drives and then surrendered them for chasing the household cat.

I also found a consistent failure to use resources among people who surrendered cats for the most common feline behavioral problem: urinating outside the litter box. This behavior is often due to urinary tract problems, but few guardians who surrendered cats had even taken the step of seeing a veterinarian. Cats, especially males, are subject to a number of urinary tract problems, but most of them are treatable or manageable with medication or a change in diet. When urination becomes painful, cats, perhaps associating the pain with the litter box, will try to find a less painful place to go. However, only half of the guardians who surrendered cats for litter box problems had ever taken their cat to a veterinarian. This finding, too, is supported by other studies. Gary Patronek and associates (1996a) found that cats who had never visited a vet were at increased risk for relinquishment, compared to cats who had been to a vet.

Some cats' elimination problems stemmed from guardians' failure to respect the cat's need for cleanliness and consistency. The following interview excerpt offers a good example of a guardian's lack of awareness:

G: [The cat] started peeing on my bed. On my bed! I mean, I love her, but I can't have her peeing on my bed!!

LI: When did it start?

G: Well, I first noticed it when we got [another female cat]. Then my daughter brought home this other cat that her boyfriend couldn't keep, so it started right when the other cat came, and by the time we had a third, she had just about ruined my bed.

LI: How many litter boxes do the cats have?

G: Just one.

LI: How often do you clean it?

G: About twice a week, usually.

LI: Where do you keep it?

G: It's down in the basement. That's another thing. It used to be in here in the hallway, but once we got more cats, the traffic was-they were always underfoot, so we moved it. We moved it a couple of times, and then settled on keeping it in the basement. Then they started fighting on the basement stairs when they had to pass each other to go down there, but it's the best place for us because it's out of the way. It was a real mess.

The woman had no idea that the number of cats in a household affects behavior, as does the cleanliness of the litter box, its location, and the type of litter used. Since any basic cat care book would contain this information so vital to a cat's well-being, this woman's situation shows how ill prepared she was to have a single cat, much less several of them. Her case is illustrative of many in which the institution provides ample information about animals' needs, but the clients toward whom that information is directed do not see the problem as one solved by information.

\section{Conclusion}

This study of the problem of unwanted pets poses a pair of related questions for the study of social problems generally: what generic processes are involved in the construction of widely acknowledged social problems, and what can we learn about them by looking at the 
relatively insignificant problem of unwanted pets? With regard to the latter question, this study demonstrates how crucial aspects of social problems construction can be more apparent in relation to marginal problems than to more culturally recognized phenomena, such as poverty or crime, whose problem status is generally taken for granted. This study also highlights the role of institutional thinking in social problems construction.

In claiming that institutions such as The Shelter "think" differently than clients do about social problems, this article raises an implicit question about differences in perspectives on social problems. I have used the term institutional "thinking" as a guiding metaphor, but can illuminate the dynamics that make the metaphor work. In particular, my analysis shows how institutional thinking produces versions of problems (and solutions) that are at odds with the lived experiences of people outside the organizational setting that ostensibly deals with those problems.

In this instance, I have shown how institutional discourse characteristics of The Shelter do not necessarily comport with accounts and descriptions offered by shelter clients. This may be a frequent upshot of institutional thinking more generally. For example, institutional or organizational discourse crafted by bureaucrats or policymakers may portray problems like homelessness or welfare reform in terms which do not strongly resonate with the terms through which actual lived experience is understood (see, for example, Haney and March 2003). This may lead to disjunctures over what is deemed "necessary" to solve putative problems. As Loseke argues, the complexities of lived experience may not be convincingly captured in institutional formulations, leading to "discursive disjunctions" (Chase 1995) between incompatible systems of meaning (Loseke 2001:123). As we have seen in the circumstances confronting shelter workers and their clients, such disjunctions can lead to confusion, conflict, and failure to resolve problems.

This article highlights three aspects of organizational discourse that produce institutional thinking that is at odds with the experience of clients. The first of these is a series of paradoxes that apply to the relationship between social progress and social problems, in general. These paradoxes highlight the ways that institutional insiders must navigate among contradictory assumptions and evidence about the problems with which they deal. I add three paradoxes of my own to the four outlined by Joel Best in his 2000 Presidential Address to the Midwest Sociological Society.

First, Best (2001) calls attention to the paradox of perfectionism. By this, he means that looking toward the elusive goal of eliminating social problems can obscure actual progress in ameliorating them. In the context of sheltering, focusing on the failure to eradicate the problem of unwanted pets means overlooking significant accomplishments in areas such as sterilization and humane education. Second, the paradox of proportion means that "reducing large problems makes smaller problems seem relatively larger" (Best 2001:1). For example, the establishment of the first shelters reduced the significant hazards associated with roaming animals in cities. However, doing so pushed smaller problems, such as sterilization and animal behavior, to center stage. Third, the paradox of proliferation "encourages recognition of a larger number of problems" (Best 2001:1). Within the realm of sheltering, the problem of unwanted animals has proliferated into problems of behavioral management, humane education, sterilization, veterinary care, animal-friendly housing, and others discussed in this article. Fourth, the paradox of paranoia means that the perceived number and size of social problems fosters intense fear and suspicion. Just as the rhetoric following 9/11 spawned new fears of terrorism and suspicion of suspected terrorists, the rhetoric of sheltering exacerbates concerns over the infinite horrors that await animals around every corner, even at the hands of their human caretakers.

To these four, I add the paradox of popularization. ${ }^{7}$ This refers to framing social problems in ways that win popular support but exacerbate or ignore aspects of the problem that do not fit

7. I thank Spencer Cahill for this term. 
the frame. For example, Leslie Miller (1997) has written about the way the "street" is framed as "dangerous" compared to its counterpart, the "safe" home. The popular framing of social problems from rape to child abduction depicts these crimes as occurring in the streets. However, data reveal that family members or dates, not strangers, commit most rapes, and parents are most often responsible for child abductions. Framing problems differently might lead to better solutions, but the public might be less amenable to such frames. Moreover, the framing sets the institutional thinking in motion and, once started, the attendant social problems work is hard to stop or reverse.

The institution of sheltering thinks about the animal problem in terms of providing practical solutions to a public that is cast as sharing similar concerns. Moreover, those who are not receptive to such solutions and would prefer to "get rid of" their animals can do so and maintain their moral identities as the "good" ones. Making surrender easier for guardians is effective social problems work, in that it enhances the organization's image in the community, but it decreases the likelihood that guardians will take any steps to improve things. Because shelters unquestioningly absorb the results of the public's irresponsibility, they may protect people more than they do animals. Shelters essentially say to the public, "We will take in your canine and feline mistakes and inconveniences, and we will shield you from the 'dirty work' that takes place here." In most shelters today, the majority of animals are not sickly strays or litters of puppies and kittens, but healthy, unwanted, adult pets. About 80 percent of these animals do not find new homes. Instead, they are humanely killed. Although precise estimates are impossible because the number of shelters in the United States is unknown, indications are that shelters kill as many as two million dogs and four million cats annually (Patronek et al. 1996a, 1996b). This makes shelter killing the leading cause of death among dogs and cats. Alternative framing might better address the conditions that create the problem of unwanted animals, but the guilt such frames might heap on the public would drive them away. Instead, the existing institutional "thinking" courts public support but reproduces numerous aspects of the problem. Even an apparently positive step such as building a new, efficient, lightflooded shelter could reproduce the problem. If clients see the setting as appealing, this may decrease the negative emotional response toward the animals' circumstances, and thereby decrease the motivation to adopt.

The paradox of popularization contributes to what I call the paradox of permutation. This refers to the transformation of good clients into bad ones. A client is defined as "good" for surrendering an animal when a problem occurs. However, from the perspective of the institution, most problems can be solved using The Shelter's resources and solutions. The key institutional problem is that clients do not use the resources provided. Thus, the "good" client who surrenders a problematic animal is simultaneously a "bad" client who remains ignorant despite the efforts of the institution. This is evident in the hostility and resentment the staff manifests toward clients "backstage." Not surprisingly, The Shelter attracts employees who consider themselves animal lovers (see also Arluke and Sanders 1996; Balcom and Arluke 2001; Frommer and Arluke 1999). Many workers who have moved repeatedly and kept their animals often find it hard to imagine why others would not do the same. Similarly, those who have solved or managed behavioral problems cannot understand why others would not want to do so, as well. For them, the commitment to an animal may mean making compromises in where one lives, or choosing an animal over a boy- or girlfriend. In other research, shelter workers claimed, "that they would never make the kinds of mistakes or decisions that people who surrender animals to them make regularly" (Frommer and Arluke 1999:10-1). Other studies of shelter employees found a similar "intolerance for those owners who seek to relinquish their dogs or cats, and a general refusal to accept that any reason for surrender is justifiable" (DiGiacomo et al. 1998). The paradox of permutation thus reinforces the already significant disconnect between the institutional and public definitions of the problem and its solutions.

A final paradox I will add is the paradox of progression. It describes how one social problem develops into others. Social problems organizations, once established, seldom go out of business. 
Instead, they find new problems or "piggyback" new versions onto existing ones. For example, when the problem of roaming animals diminished, the treatment of unclaimed strays became problematic. When shelters offered a solution to that problem, the new problem became one of uncontrolled breeding. When sterilization reduced breeding, the problem became one of unwanted pets. As Howard Becker (1963) explains, a successful "moral crusade" must find a new mission (pp. 152-4). If this is so, then the unwanted pet problem might someday be resolved, resulting in a new set of concerns that occupy shelters and justify their existence.

A second aspect of organizational discourse that produces institutional thinking that differs from the experience of clients is the "descriptive tyranny of forms" (Gubrium, Buckholdt, and Lynott 1989). As I have said, the descriptive demands of paperwork increase bureaucratic efficiency but run roughshod over the complexity of the narratives offered by clients. Gubrium and associates (1989) point out that description is seldom if ever "precisely representational of whatever it describes" (p. 212). Social problems workers often recognize the "contradictions between what they claim to know and what a form descriptively demands" (p. 212). With the development of software that further rationalizes form-completion, the tyranny can only increase. The implications of this for institutional thinking are serious. If institutions think by providing models through which experience is processed, the reduction of client needs to a selection of prescribed terms on pull-down menus reflects how organizational discourse and practices reproduce particular characterizations of social problems and solutions. As software increases the capacity for recording the frequencies with which particular terms appear, the institutional model gains strength.

Third, institutional thinking is also buttressed by the extent to which clients use legitimating rationales, or what C. Wright Mills (1940) referred to as "vocabularies of motive." ${ }^{8}$ In the everyday use of the word, "motive" is generally taken to refer to an internal cause of conduct. In Mills' sense, however, people construct and offer motives after the act, when their conduct comes under actual or potential scrutiny from others. When we express motives for something we have done, we are not, according to Mills, describing our actions. We are influencing others, as well as ourselves, to see our actions in a particular light, and we often find new motives along the way. Thus, an account of the surrender of an animal might begin with moving, but go on to incorporate allergies. By placing blame for our actions on factors such as moving or allergies, the avowal of motives mitigates responsibility for our conduct, and in doing so reduces blame. Thus, motive talk restores our own sense of self-approval. In this way, motives are similar to the "techniques of neutralization" examined by Gresham Sykes and David Matza (1957). These neutralize negative attributions and help clients to "save face," but they also incapacitate the social controls intended to check the problem. For instance, in the context of The Shelter, rationales such as moving or allergies cloak the conditions for surrender in culturally accepted terms. The client neutralizes disapproval from others and thereby maintains his or her sense of self-approval. Simultaneously, however, as Sykes and Matza point out, "the [client] both has his cake and eats it too, for he remains committed to the dominant normative system and yet so qualifies its imperatives that violations are 'acceptable' if not 'right'" (p. 667). In this way, the resources that The Shelter and other organizations offer go underutilized, for the rationalizing client can explain how they really did not apply to him or her.

The disjuncture between institutional "thinking" and lived experience calls attention to how social problems organizations are themselves the products of ongoing social problems work. Successful claims-making means that workers within such organizations see problems and clients in particular ways. These organizational frames cannot capture the complexity of clients' lived experience. As a result, workers and clients compete over definitions of reality. The

8. "Vocabularies of motive" include the linguistic conventions that Scott and Lyman (1968) refer to as "accounts," and what Stokes and Hewitt (1976) call "aligning actions." 
outcome of the competition can have important consequences. It can prevent help-seeking or even cause outright denial of problems when individual cases do not match up with organizational frames (see also Loseke 2001 for a similar case involving battered women's shelters). In the end, then, the social problems work associated with the problem of unwanted dogs and cats has implications far beyond the concern for pets and their people.

\section{References}

Adler, Patricia A. and Peter Adler. 1987. Membership Roles in Field Research. Newbury Park, CA: Sage.

American Veterinary Medical Association (AVMA). 1997. U.S. Pet Ownership $\theta$ Demographics Sourcebook. Schaumburg, IL: Center for Information Management of the American Veterinary Medical Association.

Arkow, Phillip S. and Shelby Dow. 1984. "The Ties That Do Not Bind: A Study of the Human-Animal Bonds That Fail." Pp. 348-54 in The Pet Connection: Its Influence on Our Health and Quality of Life, edited by R. Anderson, B. Hart, and L. Hart. Minneapolis, MN: Center to Study Human-Animal Relationships and Environments.

Arluke, Arnold and Clinton R. Sanders. 1996. Regarding Animals. Philadelphia, PA: Temple University Press.

Balcom, Sarah and Arnold Arluke. 2001. "Animal Adoption as Negotiated Order: A Comparison of Open versus Traditional Shelter Approaches." Anthrozoös 14:135-50.

Becker, Howard. 1963. Outsiders: Studies in the Sociology of Deviance. New York: Free Press.

Becker, Howard and Blanche Geer. 1960. "The Analysis of Qualitative Field Data." Pp. 652-60 in Organizational Research, edited by R. Adams and J. Preiss. Homewood, IL: Dorsey.

Best, Joel. 1990. Threatened Children. Chicago: University of Chicago Press.

- 2001. "Social Progress and Social Problems: Toward a Sociology of Gloom." The Sociological Quarterly 42:1-12.

Brestrup, Craig. 1997. Disposable Animals: Ending the Tragedy of Throwaway Pets. Leander, TX: Camino Bay Books.

Chase, Susan E. 1995. Ambiguous Empowerment: The Work Narratives of Women School Superintendents. Amherst: University of Massachusetts Press.

Cohen, Stanley. 1985. Visions of Social Control. London: Basil Blackwell.

Coleman, Sidney H. 1924. Humane Society Leaders in America. Albany, NY: American Humane Association.

DiGiacomo, Natalie, Arnold Arluke, and Gary Patronek. 1998. "Surrendering Pets to Shelters: The Relinquisher's Perspective." Anthrozoös 1 1:41-51.

Douglas, Mary. 1986. How Institutions Think. Syracuse, NY: Syracuse University Press.

Duvin, Ed. 1989. "In the Name of Mercy." animalines 4.11.

Finsen, Lawrence and Susan Finsen. 1994. The Animal Rights Movement in America: From Compassion to Respect. New York: Twayne.

Franklin, Adrian. 1999. Animals and Modern Cultures: A Sociology of Human-Animal Relations in Modernity. London: Sage.

Frommer, Stephanie S. and Arnold Arluke. 1999. “Loving Them to Death: Blame-Displacing Strategies of Animal Shelter Workers and Surrenderers." Society and Animals 7:1-16.

Gubrium, Jaber. 1992. Out of Control: Family Therapy and Domestic Order. Newbury Park, CA: Sage.

Gubrium, Jaber F., David R. Buckholdt, and Robert J. Lynott. 1989. "The Descriptive Tyranny of Forms." Pp. 195-214 in Perspectives on Social Problems, vol. 1, edited by J. Holstein and G. Miller. Greenwich, CT: JAI Press.

Haney, Lynne and Miranda March. 2003. “Married Fathers and Caring Daddies: Welfare Reform and the Discursive Politics of Paternity." Social Problems 50:461-81.

Hewitt, John and Peter Hall. 1973. "Social Problems, Problematic Situations, and Quasi-Theories." American Sociological Review 38:367-74.

Holstein, James A. 1992. "Producing People: Descriptive Practice in Human Service Work." Pp. 23-39 in Current Research on Occupations and Professions, edited by G. Miller. Greenwich, CT: JAI Press.

Holstein, James A. and Gale Miller, eds. 1993. Reconsidering Social Constructionism: Debates in Social Problems Theory. New York: Aldine de Gruyter. 
Irvine, Leslie. 2002. “Animal Problems/People Skills: Emotional and Interactional Strategies in Humane Education." Society $\theta$ Animals 10:63-91.

Johnson, John M. 1995. "Horror Stories and the Construction of Child Abuse." Pp. 17-31 in Images of Issues: Typifying Contemporary Social Problems, edited by J. Best. New York: Aldine de Gruyter.

Joneja, Janice Vickerstaff and Leonard Bielory. 1990. Understanding Allergy, Sensitivity, and Immunity: A Comprehensive Guide. New Brunswick, NJ: Rutgers University Press.

Kass, Philip H., John C. New, Jr., Janet M. Scarlett, and Mo D. Salman. 2001. “Understanding Animal Companion Surplus in the United States: Relinquishment of Nonadoptables to Animal Shelters for Euthanasia." Journal of Applied Animal Welfare Science 4:237-48.

Kete, Kathleen. 1994. The Beast in the Boudoir: Petkeeping in Nineteenth-Century Paris. Berkeley, CA: University of California Press.

Lawson, Nancy. 2000. “Teaching People and Their Pets." Animal Sheltering 23 (March-April):7-17.

Loseke, Donileen R. 1989. "Creating Clients: Social Problems Work in a Shelter for Battered Women." Pp. 173-94 in Perspectives on Social Problems, vol. 1, edited by J. Holstein and G. Miller. Greenwich, CT: JAI Press.

1992. The Battered Woman and Shelters. Albany, NY: State University of New York Press.

1999. Thinking About Social Problems: An Introduction to Constructionist Perspectives. New York: Aldine de Gruyter.

- 2001. "Lived Realities and Formula Stories of 'Battered Women.'" Pp. 107-26 in Institutional Selves: Troubled Identities in a Postmodern World, edited by J. Gubrium and J. Holstein. New York: Oxford University Press.

McHugh, Jan. 1999. "In Adopters We Trust." American Humane Association Leadership Forum. Denver, CO: American Humane Association.

McRae, Roswell. 1910. The Humane Movement. New York: Columbia University Press.

Miller, Deborah D., Sara R. Staats, Christie Partlo, and Kelly Rada. 1996. "Factors Associated with the Decision to Surrender a Pet to an Animal Shelter." Journal of the American Veterinary Medical Association 209:738-42.

Miller, Gale. 1983. "Holding Clients Accountable." Social Problems 31:139-51.

. 1987. "Producing Family Problems." Symbolic Interaction 10:245-65.

1992. "Human Service Practice as Social Problems Work." Pp. 3-22 in Current Research on Occupations and Professions, edited by G. Miller. Greenwich, CT: JAI Press.

Miller, Gale and James A. Holstein. 1989. "On the Sociology of Social Problems." Pp. 1-16 in Perspectives on Social Problems, vol. 1, edited by J. Holstein and G. Miller. Greenwich, CT: JAI Press.

. 1997. "Introduction: Social Problems as Work." Pp. ix-xxi in Social Problems in Everyday Life: Studies of Social Problems Work, edited by G. Miller and J. Holstein. Greenwich, CT: JAI Press.

Miller, Leslie J. [1990] 1997. "Safe Home, Dangerous Street: Remapping Social Reality in the Early Modern Era." Pp. 3-23 in Social Problems in Everyday Life: Studies of Social Problems Work, edited by G. Miller and J. Holstein. Greenwich, CT: JAI Press.

Mills, C. Wright. 1940. "Situated Actions and Vocabularies of Motive." American Sociological Review 5:904913.

New, John G., Jr., Mo D. Salman, Janet M. Scarlett, Philip H. Kass, Jayne A. Vaughn, Stacy Scherr, and William J. Kelch. 1999. "Moving: Characteristics of Dogs and Cats and Those Relinquishing Them to 12 U.S. Animal Shelters." Journal of Applied Animal Welfare Science 2:83-96.

Palmer, C. Eddie. 1978. “Dog Catchers: A Descriptive Study." Qualitative Sociology 1:79-107.

Patronek, Gary J., Lawrence T. Glickman, Alan M. Beck, George P. McCabe, and Carol Ecker. 1996a. "Risk Factors for Relinquishment of Cats to an Animal Shelter." Journal of the American Veterinary Medical Association 209:582-8.

- 1996b. "Risk Factors for Relinquishment of Dogs to an Animal Shelter." Journal of the American Veterinary Medical Association 209:572-81.

Pescosolido, Bernice. 1992. "Beyond Rational Choice: The Social Dynamics of How People Seek Help." American Journal of Sociology 97:1096-138.

Reitman, Judith. 2000. "From the Leash to the Laboratory." The Atlantic Monthly 286 (July):17-21.

Ritvo, Harriet. 1987. The Animal Estate: The English and Other Creatures in the Victorian Age. Cambridge, MA and London: Harvard University Press.

Salman, M. D., John C. New, Jr., Janet M. Scarlett, Philip H. Kass, Rebecca Ruch-Gallie, and Suzanne Hetts. 1998. "Human and Animal Factors Related to the Relinquishment of Dogs and Cats in 12 Selected Animal Shelters in the United States." Journal of Applied Animal Welfare Science 1:207-26. 
Salman, Mo D., Jennifer Hutchinson, Rebecca Ruch-Gallie, Lori Kogan, John C. New, Jr., Philip H. Kass, and Janet M. Scarlett. 2000. "Behavioral Reasons for Relinquishment of Dogs and Cats to 12 Shelters." Journal of Applied Animal Welfare Science 3:93-106.

Sanders, Clinton R. 1994. “Annoying Owners: Routine Interactions with Problematic Clients in a General Veterinary Practice." Qualitative Sociology 17:159-70.

. 1999. Understanding Dogs: Living and Working with Canine Companions. Philadelphia: Temple University Press.

Scarlett, Janet M., Mo D. Salman, John G. New, Jr., and Philip H. Kass. 1999. “Reasons for Relinquishment of Companion Animals in U.S. Animal Shelters: Selected Health and Personal Issues." Journal of Applied Animal Welfare Science 2:41-57.

Scott, Marvin B. and Stanford M. Lyman. 1968. "Accounts." American Sociological Review 33:46-62.

Serpell, James. 1986. In the Company of Animals. Oxford: Basil Blackwell.

Shore, Elsie R. and Kathrine Girrens. 2001. "Characteristics of Animals Entering an Animal Control or Humane Society Shelter in a Midwestern City." Journal of Applied Animal Welfare Science 4:105-15.

Spector, Malcolm and John I. Kitsuse. 1973. "Social Problems: A Re-formulation." Social Problems 21:14559.

[1977] 1987. Constructing Social Problems. Hawthorne, NY: Aldine de Gruyter.

Spencer, J. William. 1994. "Homeless in River City: Client Work in Human Service Encounters." Pp. 29-45 in Perspectives on Social Problems, vol. 6, edited by J. Holstein and G. Miller. Greenwich, CT: JAI Press.

Stokes, Randall and John P. Hewitt. 1976. "Aligning Actions." American Sociological Review 41:838-49.

Sykes, Gresham and David Matza. 1957. "Techniques of Neutralization." American Sociological Review 22:664-70.

Thomas, Keith. 1983. Man and the Natural World. London: Allen Lane.

Unti, Bernard. 1998. "Caroline Earle White." P. 362 in Encyclopedia of Animal Rights and Animal Welfare, edited by M. Bekoff. Westport, CT: Greenwood.

Zola, Irving Kenneth. 1973. "Pathways to the Doctor: From Person to Patient." Social Science and Medicine 7:677-89. 